\title{
2.2. ENTREPRENEURSHIP AS A PART OF THE SOCIO-CULTURAL CAPITAL IN SILESIA
}

\section{Summary}

This article aims to answer the question to what extent verbalized and declared entrepreneurship impact the competitiveness of the economy based on a research conducted in Silesia, Poland. In the theoretical part, entrepreneurship is pre-defined in its social meaning; this means that entrepreneurship is understood as an element of human capital. Entrepreneurship plays an important role in economic development, and one of the driving forces of entrepreneurship is the people's attitude towards these activities. The analysis which was conducted on the basis of empirical research on the economic awareness, discusses this aspect, the attitudes of different age groups towards entrepreneurship, as a possible way of working and living. The research results present the typology of the respondents due to their attitudes towards entrepreneurship based on their opinion, experiences and past or planned activities.

Keywords: Entrepreneurship, the socio-cultural capital, Poland, Silesia

\section{Introduction}

The issue of socio-cultural capital is often undertaken by sociologists. It is uncommon for entrepreneurship to be analyzed as human capital. However, this is a very topical issue as it provides knowledge on: which environments and what social categories are economically active and which ones intend to become active in the future. Interesting environments to study are former workers environments. These are the categories and social groups, where entrepreneurship and economic activity did not have great traditions, since the workers were actually required to be diligent and obedient. The article is to answer the question of whether such an environment has used the possibilities of business development in the market economy. In addition, it will be interesting to learn what social categories have developed entrepreneurship, particularly whether it has concerned the young generation. Answers to these questions will be gathered on the basis of the analysis of empirical studies conducted in the working-class environment of Silesia. In the conclusion, types of entrepreneurship operating in former workers environments will be created. 
Swadźba, U. - Cekiera, R.

\section{Entrepreneurship as part of the socio-cultural capital}

One of the adequate concepts developed on the basis of economics and social sciences is socio-cultural capital. Two terms are related to this concept: the first refers to various forms of social bonds underlying the relation of the entity with other people and social bodies; the other evokes correlates patterns, values and meanings encoded in the cultural space of regulating life activity of the entity (Putman, 2008). In turn, the concept of cultural capital, had been interpreted very broadly, and its essence was the inclusion of a number of factors, such as education, skills, cultural traditions, aspirations, habits, customs, values, and readiness to accept change (Świątkiewicz, 2000).

Entrepreneurship as one of the elements of the socio-cultural capital is also embraced within this definition (Drucker 1992). The classical theory of entrepreneurship was developed and perpetuated in the literature by Schumpeter, who saw the entrepreneur as a person characterized by creative activity involving the implementation of new concepts (Schumpeter 1962). In the presented characteristic of an entrepreneurial person made by Schumpeter, focus on the changes that are treated as a natural attribute of the person's actions.

Entrepreneurship is directly connected with the entrepreneur. It may be understood as "a willingness and ability to solve new problems in a creative and innovative way, the ability to exploit emerging opportunities and prospects, and flexibility to adapt to new conditions" (Kwarcińska - Kwarciński, 2004).

Entrepreneurship can also be understood as the ability to create an enterprise and acting in the direction of its development through the appropriate organization, management and introduction of new technologies (Piecuch, 2010). Such characteristics can be classified as socio-cultural capital. The activity towards creating one's own business, creativity, willingness to take risks and actions are the capital, which contributes to improving the competitiveness of the economy. Entrepreneurship and economic activity enable efficient functioning of the economy, facilitate their development and expansion, and make the company, and thus the economy, more competitive. The increase in competitiveness depends therefore, on the socio-cultural capital of which entrepreneurship is an important element.

\section{Evaluation of respondents' activity}

The applications presented below are based on sociological research. The concept of research was related to „economic awareness of residents of the former industrial region". The competitiveness of the economy is dependent on the activity of at least some people, manifested in the creation of companies and businesses. Not all people have predispositions or are suited to the task.

An entrepreneur person can be distinguished by several features such as dynamism and activity, the willingness to take risks, diligence, the use of emerging opportunities, and mobilization in difficult conditions. Through sociological studies, answers to whether 
certain social categories or communities manifest entrepreneurial attitudes can be found.

By studying former workers' communities the following question was used: „Which of the following sentences characterizes you and your attitude?". Table 1 shows the responses to this question.

Table 1: A sentence that best characterizes the attitude of respondents in connection with entrepreneurship (\%) $N=255$

\begin{tabular}{|l|c|c|c|c|c|c|c|}
\hline & \multicolumn{5}{|c|}{ Age of the respondent } & Total \\
\cline { 2 - 8 } & $\mathbf{1 8 - 2 4}$ & $\mathbf{2 5 - 3 0}$ & $\mathbf{3 1 - 4 0}$ & $\mathbf{4 1 - 5 0}$ & $\mathbf{5 1 - 6 0}$ & $\begin{array}{c}\mathbf{6 1} \text { and } \\
\text { more }\end{array}$ & \\
\hline $\begin{array}{l}\text { 1. When I plan something, I } \\
\text { usually manage to realize it }\end{array}$ & 9,1 & 7,0 & 15,7 & 10,6 & 8,5 & 6,5 & 10,2 \\
\hline 2. I like new challenges in life & 18,2 & 16,3 & 11,8 & 10,6 & 6,4 & 6,5 & 11,0 \\
\hline $\begin{array}{l}\text { 3. I believe that every person } \\
\text { can achieve success in life }\end{array}$ & 4,5 & 7,0 & 11,8 & 8,5 & 12,8 & 35,5 & 12,2 \\
\hline $\begin{array}{l}\text { 4. I believe that my future } \\
\text { depends on me }\end{array}$ & 27,3 & 23,3 & 25,5, & 19,1 & 6,4 & 16,1 & 18,4 \\
\hline $\begin{array}{l}\text { 5. In difficult situations I } \\
\text { motivate myself and try to cope } \\
\text { on my own }\end{array}$ & 9,1 & 20,9 & 15,7 & 27,7 & 12,8 & 6,5 & 16,9 \\
\hline $\begin{array}{l}\text { 6. If I fail, I don't make further } \\
\text { attempts to achieve my goals }\end{array}$ & 4,5 & 4,7 & 0,0 & 0,0 & 2,1 & 0,0 & 2,4 \\
\hline $\begin{array}{l}\text { 7. I avoid difficult situations, } \\
\text { even if it means that I will } \\
\text { achieve less }\end{array}$ & 0,0 & 4,7 & 2,0 & 4,3 & 12,8 & 6,5 & 5,5 \\
\hline $\begin{array}{l}\text { 8. I often start something, but } \\
\text { later feel discouraged and give } \\
\text { up }\end{array}$ & 18,2 & 9,3 & 9,8 & 4,3 & 10,6 & 0,0 & 7,8 \\
\hline $\begin{array}{l}\text { 9. I believe that in difficult } \\
\text { situations, I am entitled to help } \\
\text { from the state }\end{array}$ & 4,5 & 4,7 & 3,9 & 8,5 & 17.0 & 12,9 & 9,0 \\
\hline \begin{tabular}{l} 
10. Hard to say \\
\hline
\end{tabular} & 4,5 & 2,3 & 3,9 & 6,4 & 10,6 & 9,7 & 6,7 \\
\hline
\end{tabular}

Source: Own research and calculations

The above theorem can be divided into two groups. A selection of one of the first five (1-5) indicates activity and entrepreneurship, a selection of one of the following four (6-9) indicates the passivity. Almost $70 \%$ of respondents chose one of the first five options (Figure 1.). 
Figure 1: Activity and passivity of respondents based on questionnaire (\%) $N=255$

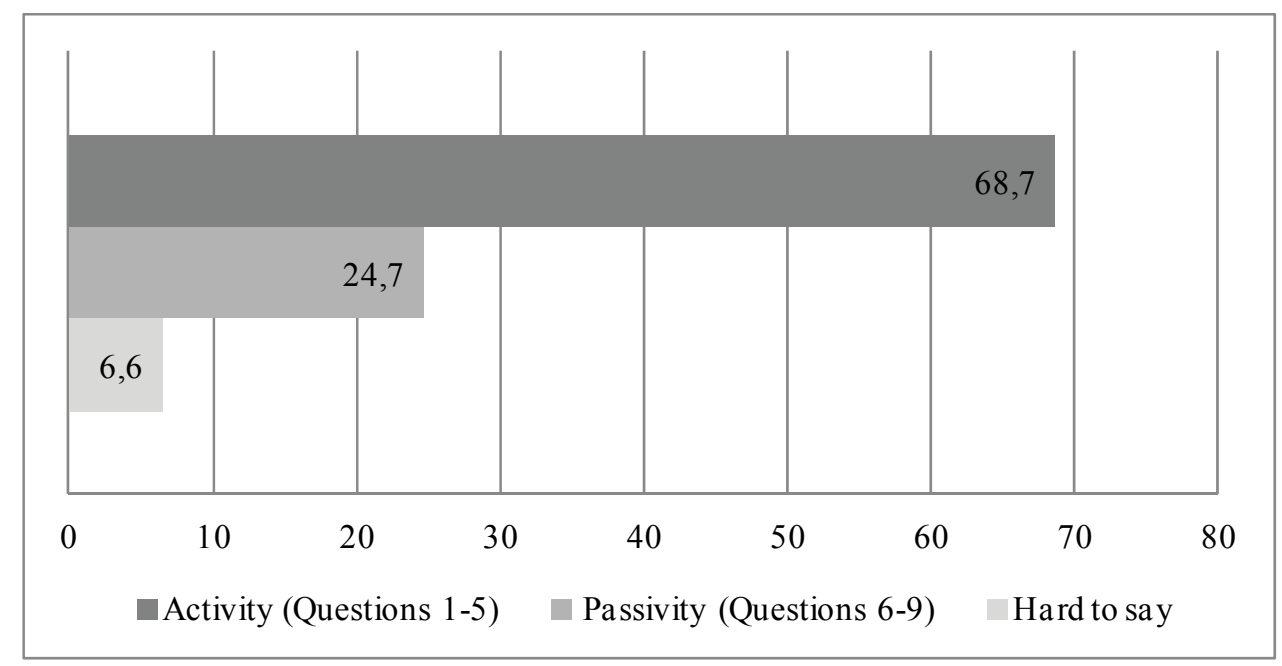

Source: Own research

As it is shown in Table 1, respondents chose most often this option: „I believe that my future depends on me" $(18.4 \%)$, it is followed by: „In difficult situations, I mobilize and try to cope on my own". Two of the possibilities no. 1 and no. 2, which evidence entrepreneurship the most, were chosen by more than $1 / 5$ of respondents $(21.2 \%)$. Such a high proportion of entrepreneurial people is a good predictor for economic development.

What are the answers of individual age groups, especially young people? First of all, the younger age categories chose the option: „I believe my future belongs to me" (about $1 / 4$ of responds). A relatively large proportion of young people under 30 years of age chose the possibility: „I like new challenges in life” (18.2\% in the age category 18 24 years, $16.3 \%$ in the age category $25-30$ years). This is very optimistic news as it shows that among young people there is a group of very active people. Unfortunately, the same percentage of young people aged 18-24 chose the answer: „It often happens to me that I start something, but later I feel discouraged and give up". The surveyed young people are therefore very polarized in their attitudes.

This is evident when one analyses the next factor - education. The biggest differences apply to answer no. 2: „I like new challenges in life” (elementary education $-2.5 \%$, basic vocational education - 7.5\%, secondary education - $13.2 \%$, higher education $20.5 \%$ ). People with higher education often chose the first five possibilities of answers (higher education - 77.4\%, elementary education - 47.5\%), and it particularly concerned young people $(84.6 \%)$. People with elementary education were more likely to choose a possibility of $6-9$ as well as ,hard to say” (elementary - 52.5\%, higher $22.7 \%$ ). The presented analysis shows that age and education both influence the assessment of one's own entrepreneurship. In workers communities, the educated young generation is optimistic about the ability to succeed, seeing career opportunities in their own activity and entrepreneurship.

In conducting research on the economical awareness, including entrepreneurship, the question about the assessment of people's suitability to running their own business was 
asked. Respondents gave the following answers: definitely yes $-11.4 \%$, rather yes $31.5 \%$, probably not $-29.5 \%$, definitely not $-15.4 \%$. This means that more than $40.0 \%$ of the respondents positively assessed their own abilities to start a business. The most confident about their own skills are people with secondary education (definitely yes $17.6 \%$, rather yes $-36.3 \%$ ), a slightly lower assessment of skills was presented by respondents with higher education (definitely yes $-13.6 \%$, rather yes $-25.0 \%$ ) and vocational education (definitely yes $-8.8 \%$, rather yes - 32.5\%). A very low assessment of their own suitability was shown by people with elementary education (definitely yes $-0.0 \%$, rather yes $-6.3 \%$ ).

The analysis shows that, above all, young people and middle-aged people to 40 years of age evaluate their suitability for self-employment very positively. About a quarter of them believe to possess the appropriate skills (25-30 years of age: definitely yes $16.3 \%$, rather yes $-15.7 \% ; 31-40$ years of age: definitely yes - $41.9 \%$, rather yes $33.3 \%$ ). Among older generations there was a decrease in self-believe. What may be the reason for such a big difference? First of all, the older generation is professionally stabilized and if someone did not set up their own business, but only worked in companies or public and private institutions, it is unlikely this person would want to take the risk in an older age. Secondly, the older generation grew up in a period of real socialism, where self-employment was limited. Therefore, they were unable to socialize to taking this kind of risk and did not have the possibility to verify whether or not they possess this type of predisposition. The young generation, socialized in the spirit of entrepreneurship and activation and is not afraid to evaluate their skills and aptitudes.

\section{The realities and plans for one's own business}

Suitability to economic activity does not always translate into running one's own business. In addition to favourable external conditions, a business idea, market knowledge and gaps in the existing market, own resources, determination and courage are needed. Therefore, two questions were asked, the first one: concerning the location and nature of the work which the respondent would like to take, and the second one: taking into account the possibility of establishing one's own business. It turned out that as many as $38.1 \%$ of respondents wanted to be self-employed, $45.5 \%$ would like to work in the state workplace, $7.1 \%$ want to work in a private company, $3.1 \%$ - go abroad, and $6.2 \%$ do not want to work at all. The results are consistent with the results of nationwide research but a slightly larger proportion of respondents would like to work in the state workplace (Skrzeszewski, 2014).

Self-employment as a rule was chosen by the young people and middle-aged people to 40 years of age. These are people who grew up in a market economy when the possibility of running one's own business was already available. The older generation whose youth fell in the period of real socialism, preferred to work in state workplaces. Among the youngest it was also attractive to work in a private company. This can be explained by higher earnings than in the state workplaces. Changes in trends when it comes to choosing the type of work can also be noticed. Several years ago among 
workers' communities, work in state workplaces was preferred and far smaller interest in own economic activity was shown (Swadźba, 2001).

There are also correlations regarding education. Most likely to work „on their own” are people with secondary education $(45.5 \%)$, especially men with a technical education. These are people who already have some experience and believe in their own abilities. In contrast, a much lower proportion of respondents with higher education preferred the conduct own business $(25.5 \%)$.

People with higher education often chose the opportunity to work in a state or local workplace $(61.1 \%)$. This situation particularly concerned women, as indicated by other sociological studies (Boguszewski, 2014). The willingness to work in a specific company, always remains in the realm of projects and refers to unspecified plans. These plans do not always come true. This is often due to the external constraints, the lack of jobs in the company or institution. Added to this are internal factors, like the lack of resources to develop one's own business or the lack of qualification for employment in the job.

Sociological studies show how often career aspirations fail to comply with the realities of the labour market. Accordingly, to investigate whether or not self-employment and economic activity are just in a sphere of dreams or concrete plans, the question about life plans was asked, which take self-employment into account. Below are the answers to the second question in correlation with education.

The approach of the respondents about entrepreneurship is illustrated by Figure. 2, which shows that there is a definite aversion towards entrepreneurship.

Figure 2: Respondents' approach towards entrepreneurship (\%)

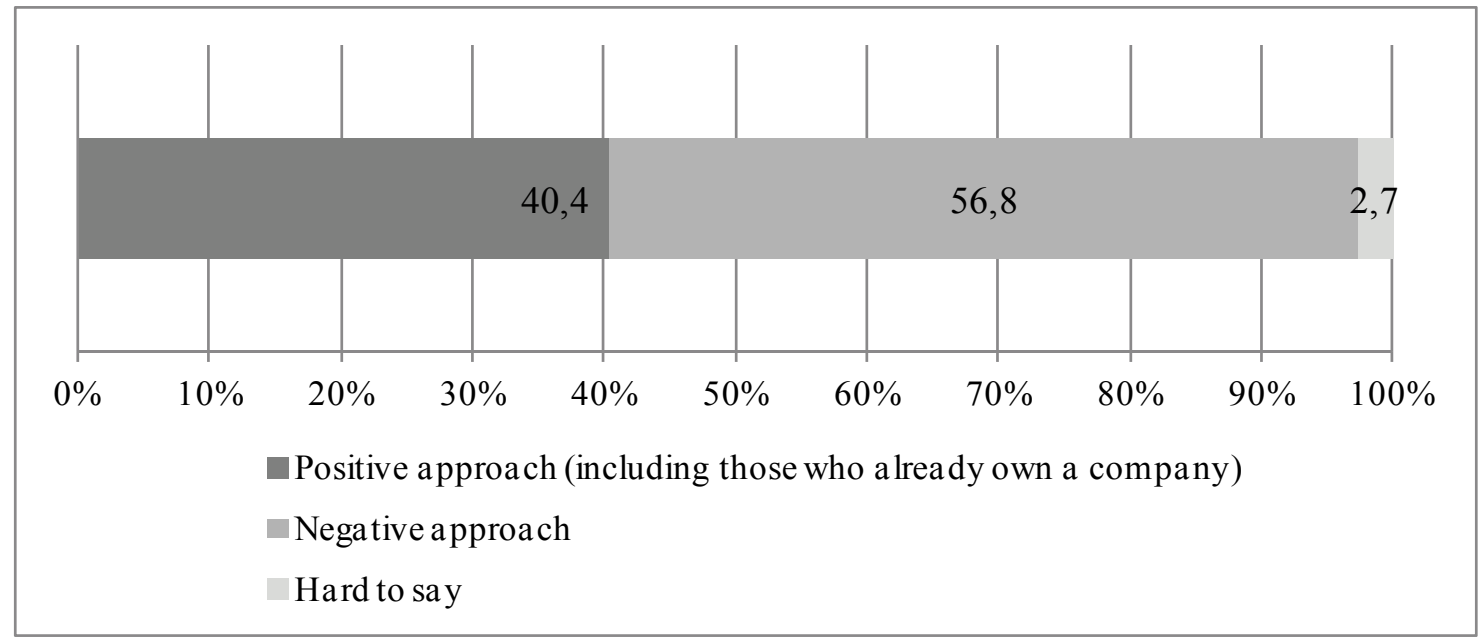

Source: own research

The approach towards entrepreneurship was evaluated by the following questions of in the questionnaire described in Table 2. 
Table 2: Do you take into consideration in your life plans the possibility of starting selfemployment, creating your own business (\%), $N=255$

\begin{tabular}{|l|c|c|c|c|c|}
\hline \multirow{2}{*}{ Answers } & \multicolumn{3}{c|}{ Education of the respondent } & \multirow{2}{*}{ Total } \\
\cline { 2 - 5 } & Primary & $\begin{array}{c}\text { Basic } \\
\text { vocational }\end{array}$ & $\begin{array}{c}\text { Second- } \\
\text { ary }\end{array}$ & Higher & T, \\
\hline $\begin{array}{l}\text { I already own (co-own) a private } \\
\text { business }\end{array}$ & 5,0 & 7,5 & 19,8 & 9,1 & 11,8 \\
\hline $\begin{array}{l}\text { I want to soon start my own } \\
\text { company }\end{array}$ & 2,5 & 2,5 & 0,0 & 4,5 & 2,0 \\
\hline $\begin{array}{l}\text { I'm thinking of starting my own } \\
\text { business in the future }\end{array}$ & 2,5 & 13,8 & 15,4 & 20,5 & 13,7 \\
\hline $\begin{array}{l}\text { I have thought about it, but have } \\
\text { not decided }\end{array}$ & 10,0 & 16,3 & 15,4 & 4,5 & 12,9 \\
\hline I have never given it much thought & 27,5 & 31,3 & 23,1 & 22,7 & 26,3 \\
\hline $\begin{array}{l}\text { I do not take this into account in } \\
\text { my plans for life }\end{array}$ & 42,5 & 25,0 & 25,3 & 25,0 & 27,8 \\
\hline $\begin{array}{l}\text { I had my own company and do not } \\
\text { intend to assume the next one }\end{array}$ & 2,5 & 0,0 & 1,1 & 11,4 & 2,7 \\
\hline $\begin{array}{l}\text { Other possibilities, it is difficult to } \\
\text { say }\end{array}$ & 7,5 & 3,8 & 0,0 & 2,3 & 2,7 \\
\hline
\end{tabular}

Source: Own research and calculations.

The research results show that more than half of the respondents never thought about starting their own business, or does not take this into account in their life plans.

Slightly less than half of the respondents have thought of starting their own business, but decided not to, and slightly higher proportion of people thinks of starting a business in the future. A relatively high proportion of respondents $(11.8 \%)$, already owns their companies, they mostly have secondary education. A low percentage of respondents has already had a business and do not intend to assume the next one in the future ("I had my own company and do not intend to assume the next one"). Perhaps this is due to bad experiences, and perhaps it is a result of poor skills. However, often these people hold a higher education degree. One can therefore deduce that higher education has not been matched with the skills of running a business.

To which social categories do the entrepreneurial people and those already leading their own businesses belong to? These are mainly people with secondary education (almost 20\% of the respondents). Primarily graduate technicians decide to run their own businesses, after several years of work and gathering of experience. Lower by about a half is the proportion of people with higher education. The next influencing feature is gender. Definitely more business owners are men $(14.3 \%)$ than women $(9.4 \%)$. Age is also a decisive premise. Business owners are mostly people between 30 and 50 years of age $(31-40-30.5 \%, 41-50-14.9 \%)$.

An overrepresentation of young people up to 40 years of age occurs. This means that the socialization of the young generation in a market economy brings certain results. The young generation, particularly men, is not afraid of entrepreneurship and economic activity. Overrepresentation of people with a secondary education may also result from the nature of the environment in which the study was conducted - former 
and current workers districts, where this category of citizens prevails. This is particularly true in case of Giszowiec, inhabited by workers employed in mines. A slightly lower percentage of people with higher education have their own businesses (9.1\%). They are also the most commonly men at a younger age. This category of respondents has more specific plans for the development of their own economic activity. In the nearest future $4.5 \%$ of respondents intend to undertake this type of activity. Almost all people with their own businesses believe that they have predispositions to such activity (definitely yes $-46.7 \%$, rather yes $-43.3 \%$ ). It is a good omen for competitiveness and economic growth as it means that active people fulfil themselves in their professions and succeed.

Also, a relatively high percentage of respondents $(13.2 \%)$ plan to start their own business in the future. Are there differences in responses between different social categories? People with higher education most often think about starting their own business in the future (1/5 of them have such plans). Primarily young people have 'starting a business' in their life plans (up to $37.2 \%$ of people aged $37.2 \%, 27.3 \%$ of people aged $37.2 \%$ and $15.7 \%$ of those aged $31-40$ years). As a general rule, young people assume that it is possible to change career plans several times in order to find the right place and settle down (Boguszewski, 2013).

What is surprising, there is no gender difference when it comes to the answer to this question. Almost the same proportion of women and men has such life plans for the future. This means that, first of all, young women do not feel complexes when it comes to their skills and plans for their own economic activity. However, when analysing in more detail the differences between the desire of economic activity for men and women, one can see some distinctions. Women want to become economically active slightly later than men. At the age of 18-24 years, a higher proportion of men already plan to set up a business ( $\mathrm{M}-37.5 \%, \mathrm{~F}-21.4 \%)$, while in case of women such plans only develop at the age of 25-30 years (M - 33, 3\%, M - 40.0\%). In the age category of $31-40$ years such plans are held by only $7.7 \%$ of women and $24.0 \%$ of men. What may cause such an age diversity of plans? Probably the fact, that women often undertake studies, and only after graduation do they plan to take such a risk. Men set up their companies already in college, and some of them encouraged by the example of their peers plan such activity for the nearest future. It should be noted, however, that young women present the same level of economic activity as men, and due to the fact that they are better educated, it presages well for the future. Sociological studies show the current situation to be more conducive to entrepreneurial people, and people with an idea and the energy, supply the sector of private enterprises (Kowalczuk, 2013).

What is interesting, people who plan to start their own business do not always assess their suitability for this kind of project properly. Only $20.7 \%$ of them evaluated it positively and answered "definitely yes", and 23.3\% - "rather yes". It is not a good omen for providing business skills for the future business owners. However, it can be assumed that as a rule those are young people, therefore they will still manage to prepare for such activity.

The respondents in the older age categories most often do not think about taking such life activity (over $30 \%$ of responses). This is particularly true in relation to women with primary education, but also with secondary or higher. Such categories of 
respondents are very reluctant to undertake economic activity. It also derives from the fact that middle and the older generations are professionally stabilized and if not forced by the external factors, they do not want to change the existing situation. Careers and activity are implemented in the workplace. But what is interesting, very young women, of less than 24 years of age, also do not think about starting a business. Perhaps this is due to the fact that they rather think about undertaking studies or graduation, and finding a job in the public or private sector. Only then, after graduation in the face of the reality of the labour market, would they change their minds on this issue.

\section{Conclusions}

The analysis of studies carried out in a fairly homogeneous environment, allows for a number of generalizations and conclusions to be made. Generalizations in fact allow for identifying several types of entrepreneurship in the Polish society. The main criterion for distinction, is the ratio of economic activity and age, however gender and education must also be taken into account. The different groups according to their attitudes towards entrepreneurship in the Polish society are as follows:

1) Active: The entrepreneurs, self-employed, young and middle aged, mostly men with secondary education. Those people are confident about their predispositions for running a business and succeed in this field.

2) Resilient: People who only plan economic activity, without specified plans. They are not afraid of new challenges and activities. This type includes young people, slightly more often young men, especially up to 25 years of age and women slightly older than men (25-30 years of age). In the case of the young men, they have completed high school, often still studying, while women belong to the post-graduation group. For now, they do not assess their suitability for business planning positively, however considering their young age, they still have time to improve the necessary skills. This is a group that demonstrates a high level of entrepreneurship. People, who were socialized in times of market economy, consider their own economic activity as a natural career path.

3) Conservative: People in the younger and middle age categories, more often women. They completed higher education and do not consider economic activity in their life plans. They are reluctant to take up new challenges, and therefore often look for a stable job in the public sectors. They assess their suitability to run business poorly and therefore do not take this into account in their life plans.

4) Stabilized: People in the middle and old age categories, of both genders and various levels of education. They have achieved professional stabilization and succeeded in varying degrees. Those people rather do not consider any changes in this situation and do not intend to demonstrate entrepreneurship. Only external factors, such as job loss, change in the family situation, sometimes force them to undertake economic activity. These are the people who partially lived their lives in the period of real socialism.

5) Retreated: Older people of both genders, ending their professional career or already retired. Their youth and significant part of economic activity fell in the 
period of real socialism; therefore they were never socialized to develop their own economic activity.

Economic development is not only conditioned by legal, political, technological and financial issues, but also by the actions of individuals, their activity and entrepreneurship. The conducted analyses indicate that some members of the former working-class communities manifest entrepreneurship and implement it in their lives by setting up their own businesses. This potential mainly lies in the young generation, socialized in a market economy. Creativity and entrepreneurship of the young generation of former working class communities are important predictors for the development of the region.

\section{References}

1. Boguszewski, R. (2013): Kobieta pracująca, Komunikat z badań CBOS, (BS/28/2013), www.cbos.pl, (online: 16.03.2014).

2. Boguszewski, R. (2013): Mobilność i elastyczność zawodowa Polaków, Komunikat z badań CBOS, (BS/11/2013), www.cbos.pl, (online: 10.11.2014).

3. Drucker, P. F. (1992): Innowacja i przedsiębiorczość. Praktyka i zasady, Państwowe Wydawnictwo Ekonomiczne, Warszawa.

4. Kowalczuk, K. (2014): Polacy o gospodarce wolnorynkowej, Komunikat z badań CBOS, (Nr 31/2014), www.cbos.pl, (online: 16.03.2014).

5. Kwarcińska, A.; Kwarciński, K. (2004): Przedsiębiorczość jako czynnik konkurencyjności gospodarki. In: Człowiek a rynek, Partycki, S. (ed.), Wydawnictwo Katolickiego Uniwersytetu Lubelskiego, Lublin.

6. Piecuch, T. (2010): Przedsiębiorczość. Podstawy teoretyczne, H.C.Beck, Warszawa.

7. Putnam, R. (2008): Samotna gra w kręgle: upadek i odrodzenie wspólnot lokalnych w Stanach Zjednoczonych, Wydawnictwa Akademickie i Profesjonalne, Warszawa.

8. Schumpeter, J. (1962): Teoria rozwoju gospodarczego, Państwowe Wydawnictwo Ekonomiczne, Warszawa.

9. Skrzeszewski, M. (2010): Polacy o prowadzeniu własnego biznesu, Komunikat z badań CBOS, (BS/158/2010), www.cbos.pl, (online: 10.11.2014).

10. Swadźba, U. (2001): Śląski etos pracy. Studium socjologiczne, Wydawnictwo Uniwersytetu Śląskiego, Katowice.

11. Świątkiewicz, W. (2000): Wokół socjologicznej koncepcji kapitału społecznokulturowego. In: Kapitał społeczno-kulturowy a rozwój lokalny i regionalny, Szczepański, M. (ed), Wydawnictwo Wyższej Szkoły Zarządzania i Nauk Społecznych, Tychy. 